\title{
Opening speech
}

\section{Victor Nabhan*}

Ladies and Gentlemen,

Dear Friends,

In 1812 a book was published, the title of which is very telling. It was called 'Calamities and Quarrels of Authors'. In this book, the author, Isaac Disraeli, draws a rather bleak picture of the situation of authors.

'In all nations of Europe, [he asserts] authors, though they have been the most honored, were nevertheless the least remunerated.'

'Authors continue poor', he goes on, 'and booksellers become opulent'. 'They are heirs to fortunes, but by a strange singularity they are disinherited at their birth; for, on the publication of their works, these cease to be their own property.'

'Most of them close their lives in apathy and despair, and too many live by means which few of them would not blush to describe.'

This dramatic description is well portrayed by a poem attributed to a mendicant author:

Forgive me, God, although I curse my birth,

And ban the air wherein I breathe a wretch!

For misery hath daunted all my mirth -

In some far land will I my griefs rehearse,

England, adieu! the soil that brought me forth!

Adieu, unkinde! where skill is nothing worth!

Despite this rather dramatic depiction, Disraeli finds, however, some reason for solace. In a chapter entitled 'The Suffering of Authors' he refers to 'That Act of Anne which confers on them some right of property, acknowledges that works of learned men have been carried on too often to the ruin of them and their families.'

300 years later, or rather 299, as the Statute of Anne was enacted in 1710 , the chance could not be missed to reflect on the importance of this historical event and to put it in proper historical perspective as well as in

\footnotetext{
* ALAI Chairman
} 
current context. Our friends from BLACA have wonderfully grabbed this opportunity by organizing this Congress.

In terms of history, the Statute of Anne was the first enactment ever to spell out the basic components that were to form the common structure of future copyright laws, that is providing for (1) exclusive rights to (2) authors, with respect to (3) a subject matter and (4) for a limited time. These are the backbones of any copyright legislation, anywhere in the world.

However, it would seem that not everybody agrees with this fact. Some even beg to differ. For example President Sarkozy emphatically stated last year, and I quote, that 'France has invented Copyright' ('La France a inventé le Copyright'). I must say that this somewhat puzzling statement was made in the aftermath of the European Football Games competition during which the French national team did not fare exceedingly well, and from which the English team was excluded. This might explain that, perhaps.

Put into historical perspective, the Statute of Anne was only but the beginning of an exponential development of copyright laws all over the world that were to provide for (1) more rights applying to (2) more subject matter and for (3) a longer period of time.

But we are witnessing now a time of profound turbulence. One may even refer to a backlash of sorts. Copyright is pointed at with an accusing finger. To such an extent that a political party running under the name of the Pirate Party, has succeeded in having one representative elected to the European Parliament. Its program is quite simple: free use of works on the net and a much shorter term of protection in general. On the other hand, active lobbying from developing countries and consumer groups requires that free use of works be expanded, and that compulsory exceptions be provided for in future treaties.

As we are in a country where understatement is a way of life, it would be fair to say that Copyright is at a crossroads. In the mind of many, at present, Copyright is not very likely to win a popularity contest. As a matter of fact, and for some, one wonders which, between swine flu and copyright, is perceived as the more hazardous! Never before, have the stakes been so high nor Copyright a more controversial topic.

The conference is thus highly, hugely timely. The topics that it will address are very relevant and quite inspiring. And speaking about inspiration, allow me to quote an extract from a poem by James Thomson, a Scot. It is entitled 'The Seasons'. Even though pompous at times it is one of the finest nature poems in English literature. And one of the longest too, as it runs over 200 pages. It has also given rise to a formidable and very long legal dispute and to two important well known court decisions: Millar $v$. 
Taylor and Donaldson v. Beckett. In this poem Thomson describes creativity in the following terms:

Come, Inspiration! from they hermit-seat, By mortal seldom found: may Fancy dare, From they fix'd serious eye, and raptured glance Shot on surrounding Heaven, to steal one look Creative of the Poet, every power Exalting to an ecstasy of soul

Drawing on this poem, I trust that this meeting will be a source of inspirational and inspired debates. And I hope that these debates will be exalting in a way that might lead to an ecstasy of our souls. Or at least, the legally inclined side of our souls!

It is thus with the utmost pleasure that I have the honor and privilege to declare open the ALAI Congress in London, to celebrate a unique and historical event: the almost tercentennial advent of the Statute of Anne. 
Victor Nabhan - 9781849806428 Downloaded from PubFactory at 04/26/2023 02:49:47PM via free access 